Argentine nuclear plans

\section{US blunders on
water transfer \\ Washington}

A LOOPHOLE in the Nuclear Non-Proliferation Act has allowed the Reagan Administration to approve the transfer of 143 tonnes of heavy water to Argentina despite indications that that country is acquiring a nuclear weapons capability. As a result, efforts are being made in Congress to tighten export controls on all nuclear material.

Argentina, which possesses substantial uranium reserves, will soon be selfsufficient in fuel fabrication and reprocessing. It already has its own uranium milling and fuel fabrication plants, and a conversion plant (where uranium ore is processed into fuel-grade uranium dioxide) supplied by West Germany and it has under construction its own conversion and reprocessing plants and a heavy water plant supplied from Switzerland. Heavy water is used as a moderator in reactors that use natural uranium fuel $(0.7$ per cent uranium). Argentina has two commercial reactors of the Canadian CANDU type.

There have recently been intelligence reports suggesting that Argentina is planning to divert as much as one tonne of uranium at the conversion stage without detection by international inspectors. Although Argentina has no uranium enrichment facilities and does not import enriched fuel that could be used directly to construct a bomb, the unenriched fuel could be irradiated in its reactors to produce plutonium, which could then be separated at the reprocessing stage for weapons use.

The sale of heavy water by the United States was approved because of a loophole that allowed the administration to circumvent the Nuclear Regulatory Commission (NRC), which must approve most transfers of nuclear fuel or components, and which is autonomous and politically independent of the executive branch. In fact, several requests for direct sales of relatively minute amounts of heavy water - 5 to 10 kilograms - to Argentina have been held up by NRC for more than a year. NRC, before approving a sale, must ensure that the country receiving the material will maintain international inspections at the site to which the material is going and pledge that that site will not be used to produce nuclear explolsives.

The 143-tonne shipment, however, is technically a "retransfer", not a sale; the material, although manufactured in the United States, is in two West German reactors scheduled for decommissioning. Retransfers need only the approval of the Secretary of Energy, a political appointee.

At recent hearings on the matter, several astonished senators heard the State
Department's ambassador-at-large for non-proliferation policy, Richard Kennedy, explain that the administration had "goofed" in not consulting Congress before approving the retransfer. Kennedy also said that the administration was satisfied that Argentina's military interest in nuclear energy was limited to propulsion for its submarines. Argentina has refused, however, to rule out the development of

nuclear explosives for "peaceful" uses.

The House of Representatives has passed an amendment to the Export Administration Act that would block both the Argentina deal and the sale, announced this summer, of spare parts for India's Tarapur reactor. The amendment requires that a strict standard, now applied only to the sale of nuclear fuel, be applied to the sale and retransfer of all nuclear materials and technological assistance: to receive such aid, a country would have to open all its nuclear facilities to international inspection and would have to pledge that it will not seek to build nuclear explosives. Similar measures are pending in the Senate.

Stephen Budiansky

\title{
US conservation
}

\section{What will happen after Watt?}

Washington

FOR all the sound and fury of James Watt's controversial reign as Secretary of the Interior, which ended much as expected last week with his resignation, he in fact accomplished few of his overt objectives. The irony of his enforced resignation is that he was in the end brought down not by a dispute over the disposal of federal lands, on which his policies have repeatedly maddened conservationists, but by a tasteless jibe that offended ethnic minorities, women and the disabled.

The surprise selection of William Clark, the President's national security adviser and close friend, to succeed Watt, however, is a sign that Watt's less-noticed accomplishments, particularly his ability to bring political rule to traditionally independent sections of the department, will live on after him. In choosing Clark, Presi-

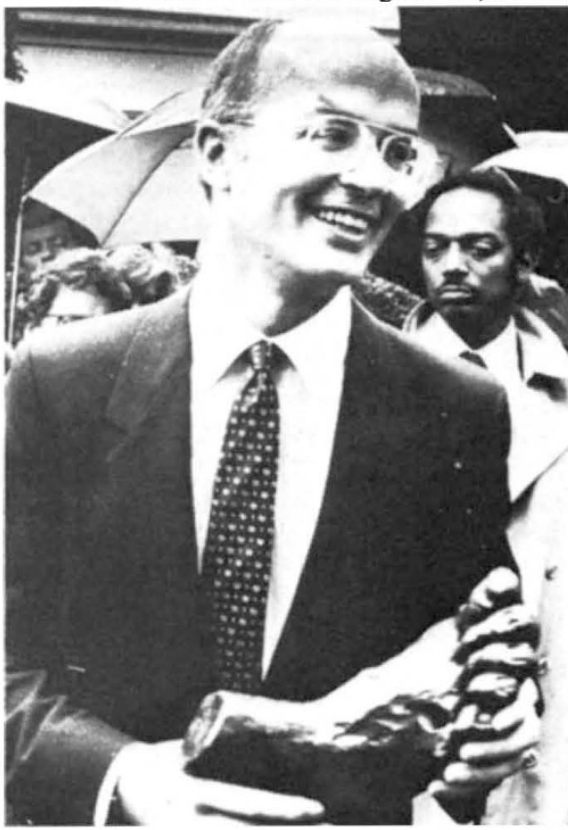

In April Presiden! Reagan awarded James Watl a model foot with a hole in it to celebrate Watt's achieverment in "shooting himself in the foot" by banning the Beach Boys rock group from Washington's Fourth of July celebrations. Wall's latest blunder was rewarded more severely. dent Reagan took the opposite tack from that he followed in bringing in William Ruckelshaus, a respected professional, to clean up the disorder left by Anne Gorsuch at the Environmental Protection Agency. Clark is in the same western-state conservative mould as Watt, and his selection is seen as a concession to the conservative wing of Reagan's party.

Watt's most controversial policies of leasing mineral rights on previously protected federal lands and coastal areas have been largely quashed by congressional action and undercut by a lack of interest on the part of the oil companies in leasing new fields at a time of over-supply and low prices. Much the same happened when Watt tried, two years ago, to sell leases on oil-shale territories in Colorado and other western states - potential bidders were reluctant to risk their own money on an unproven technology. Watt's efforts to accelerate the lease of offshore oil rights ran into restraining orders issued by federal judges in response to lawsuits by states with competing interests - mainly fishing.

Watt's greatest legacy, however, may be in the less obvious organizational changes he effected within the department. Congressional committees found repeated instances in which professionals in the department who questioned the legality or propriety of Watt's policies were transferred or harassed. By many accounts, he was thoroughly successful in eliminating the conservation interests in the department, a body of expertise that may take years to rebuild. He also brought political control within the department to a new peak by ordering professionals, including the superintendents of national parks, not to testify before congressional investigating committees.

Even the staunchly independent US Geological Survey did not escape; its conservation division, including a number of scientific personnel, was subsumed by a new Minerals Management Service, under the control of a political appointee.

Stephen Budiansky 